\title{
EFFECT OF SOIL SURFACE COMPACTION PRESSURE AND COMPACTING CYLINDER SURFACE SHAPES ON BORDER IRRIGATION EFFICIENCY
}

\author{
M. A. Kassem*, M. I. Ghonimy** and G. M. Abdel-Rahman *
}

\begin{abstract}
A field experiment was carried out at the Experimental Station Farm, Faculty of Agriculture, Cairo University. The purpose of this study is to investigate the effect of different levels of soil surface compaction pressure $(P)(15,22.5,30,37.5 \mathrm{kPa})$ and compacting cylinder surface shapes $(C)$ with protrusion spaces $(5,10,15$ and $20 \mathrm{~cm})$ on: the infiltration rate $(\boldsymbol{I R})$, percentage of water losses by deep percolation (DPP), percentage of soil moisture defect (SMD), total advance time $(\boldsymbol{A T})$, water distribution uniformity $(\boldsymbol{D u})$, water application efficiency $(\boldsymbol{E a})$, the corn crop yield $(\boldsymbol{C y})$ and the water use efficiency (WUE). All data were collected during the summer seasons of 2004 and 2005 for corn crop. For the compacted soil surface, the values of IR, DPP, SMD and $\boldsymbol{A T}$ decreased by increasing the soil surface compacting to $22.5 \mathrm{kPa}$ and by increasing protrusion space to $15 \mathrm{~cm}$. The values of $\boldsymbol{D u}$ and $\mathbf{E a}$ increased by increasing the soil surface compacting to $22.5 \mathrm{kPa}$ and by increasing protrusion space to $15 \mathrm{~cm}$. The best $\boldsymbol{C y}$ and $\boldsymbol{W U E}$ were obtained at soil surface compacting (P2) $22.5 \mathrm{kPa}$, with any compaction cylinder surface shape.
\end{abstract}

\section{INTRODUCTION}

urface irrigation is the most widely used irrigation method in Egypt especially in old Nile Valley and Delta. Surface irrigated lands face a number of difficult problems. The low efficiency of surface irrigation is one of the major problems, which causes tremendous losses of fresh water resources, used for irrigation. Allen and Schneider (1992) found that irrigation intake rate decreased by about $18 \%$ by the effect of traffic compaction on the cultivated lands.

* Assoc. Prof., Ag. Eng. Dept., Fac. of Ag.., Cairo Univ.

** Prof. ., Ag. Eng. Dept., Fac. of Ag.., Cairo Univ. 
Gemtos and Lellis (1997) reported that mean daily growth and final height of plants showed a maximum at compaction pressure around 100 to $200 \mathrm{kPa}$ at the depth $(5-20 \mathrm{~cm})$. Voorhees (1987) found that for drier conditions in the clay loam of corn fields were better in rows with planter wheel tracks than in areas away from wheel tracks. Supporting the same concept. Soane et al. (1982) stated that plant growth and yield of cereal are likely to show optimum responses at a certain level of soil compaction. The optimum level is related to soil type, crop growth stage and climatic conditions. Meanwhile Boone (1988) suggests that compaction can cause yields to increase, remain constant or decrease that are based on the optimum value of soil compaction. Ghonimy (2003) studied the effect of soil compaction on water and energy consumption in producing corn crop and he found that, the highest corn production was achieved by compaction pressure $30 \mathrm{kPa}$ at the different types of cylinder surface shape. While the maximum loss value, 267.6 LE/fed, was found at $37.5 \mathrm{kPa}$ normal pressure using the protrusion cylinder shape with $5 \mathrm{~cm}$ protrusion space. Schwankl et al. (2000) indicated that variability of furrow physical characteristics, in decreasing order of their relative impact on furrow irrigation performance, were furrow inflow rate, infiltration, geometry, and roughness. For a field with highly variable soil roughness and infiltration characteristics, spatially varying infiltration may have a greater impact than variable furrow inflow on irrigation performance. On the other hand, $\boldsymbol{E W U P}$ (1984) reported that a relative safe estimation is that 40 percent or more of the water diverted for irrigation was wasted at farm level through either deep percolation or surface run-off. Therefore, this work will concentrate on the optimum level of soil surface compacting for clay loam soil and the optimum surface shape of the cylinder soil compaction under Egyptian climatic condition.

\section{MATERIALS AND METHODS}

A field experiment was carried out at the Experimental Station Farm, Faculty of Agriculture, and Cairo University during two excessive seasons 2004 and 2005. The purpose of this research work is to explore the effect of different levels of soil surface compacting pressure $(\mathrm{P})$ and 
compacting cylinder surface shapes $(\mathrm{C})$ on the values of soil bulk density $(\lambda)$, infiltration rate (IR), total advance time (AT), opportunity time (OT), percentage of water losses by deep percolation (Dpp), percentage of soil moisture defect (SMD), water distribution uniformity (DU), water application efficiency $\left(\mathrm{E}_{\mathrm{a}}\right)$, corn crop yield $\left(\mathrm{C}_{\mathrm{y}}\right)$, and water use efficiency (WUE). Soil compaction machine (SCM) shown in fig. (1) was designed and constructed to provide different levels of soil compaction pressure (P). values of $(\mathrm{P})$ were $15,22.5,30$ and $37.5 \mathrm{kPa}$ respectively, plus uncompacted soil (Po) a control. Also the "SCM" has different types of soil compaction cylinder surface shapes (C). The first type was smooth surface (Cs) shown in fig. (2a) while the second types were protrusion surfaces $(\mathrm{Cp})$. These different types of protrusion cylinder surface shapes prepared by welding group of protrusions on the smooth cylinder. The protrusion width and height were $5 \mathrm{~cm}$ for all types. While protrusion space on the soil compaction cylinder, it takes the values of 5, 10, 15 and $20 \mathrm{~cm}$, as shown from Fig. (2b) through Fig. (2e). These different types of cylinders could be operated empty or partially filled completely or even completely filled with water, to give different pressures. Auxiliary loads may be added over the completely filled cylinder with water to fulfill certain soil pressure if it needed. From the metal cylinder weight and the contact surface area of the tested soil compaction pressures were determined. The field experiment was executed in a split plot design with four replicates. Each plot was a border $1.2 \mathrm{~m}$ width and $50.0 \mathrm{~m}$ length with soil surface slope $0.03 \%$. The water was supplied through a perforated pipe having orifices spacing of $0.6 \mathrm{~m}$ apart. The discharge rate of each orifice was measured before beginning the irrigation and it was maintained to $0.55 \mathrm{lit} / \mathrm{sec}$ for each orifice. Each border had two orifices with $1.1 \mathrm{lit} / \mathrm{sec}$ discharge rate. The experimental field was tillage two ways by chisel plow for all treatments, planting the corn seeds manually on 15 Jun for two excessive seasons of 2004 and 2005. After seeds planting, the soil was compacted by "SCM" at $4.5 \mathrm{~km} / \mathrm{h}$ of forward speed according to the treatments and data shown in table (1). The soil moisture content for the surface layers $(0-20 \mathrm{~cm})$ were measured before beginning the soil surfacing compacting and founded that $19 \%$ by weight. After 
seeds were planted, each plot was irrigated then they were irrigated 14 days apart.

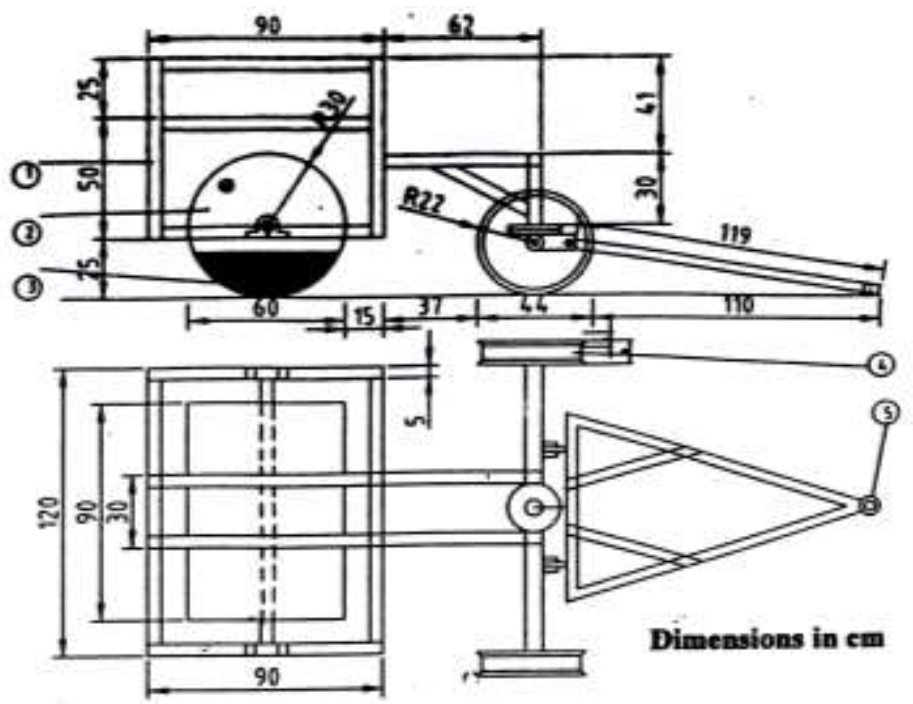

1- Frame 2-Cylinder 3-Water 4- Front wheel 5- Hitching point

Fig. (1): The components of the soil compaction machine.

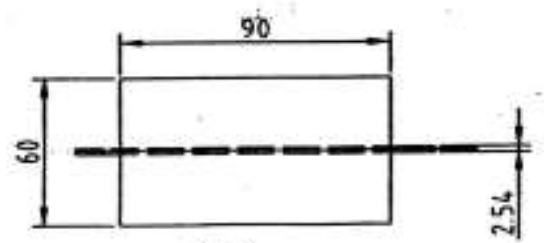

(a)
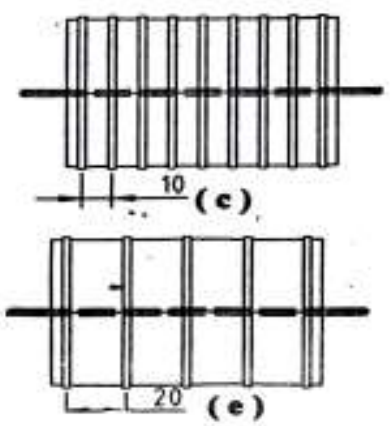
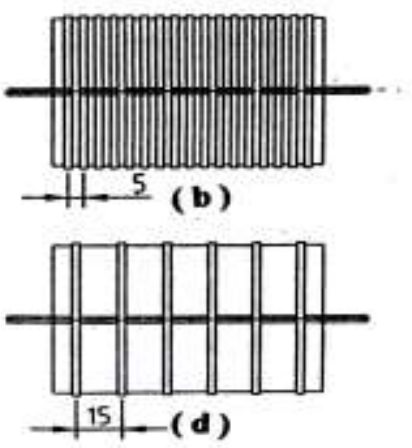

Dimensions in $\mathrm{cm}$

Fig. (2): Different types of the compaction cylinder surface shapes (C). 
Table (1): The treatments of surface soil compaction

\begin{tabular}{||c|c|c|c|c||}
\hline $\begin{array}{c}\text { Treatment } \\
\text { No. }\end{array}$ & $\begin{array}{c}\text { Treatment } \\
\text { symbols }\end{array}$ & $\begin{array}{c}\text { Cylinder Surface } \\
\text { pressure "P", } \\
\mathrm{kPa}\end{array}$ & $\begin{array}{c}\text { Cylinder } \\
\text { Surface shape } \\
\text { "C" }\end{array}$ & $\begin{array}{c}\text { Protrusion } \\
\text { space, } \\
\mathrm{cm}\end{array}$ \\
\hline 1 & P1Cs & 15 & Smooth & ------ \\
\hline 2 & P1C5 & 15 & Protrusion & 5 \\
\hline 3 & P1C10 & 15 & Protrusion & 10 \\
\hline 4 & P1C15 & 15 & Protrusion & 15 \\
\hline 5 & P1C20 & 15 & Protrusion & 20 \\
\hline 6 & P2Cs & 22.5 & Smoth & ----- \\
\hline 7 & P2C5 & 22.5 & Protrusion & 5 \\
\hline 8 & P2C10 & 22.5 & Protrusion & 10 \\
\hline 9 & P2C15 & 22.5 & Protrusion & 15 \\
\hline 10 & P2C20 & 22.5 & Protrusion & 20 \\
\hline 11 & P3Cs & 30 & Smooth & --------- \\
\hline 12 & P3C5 & 30 & Protrusion & 5 \\
\hline 13 & P3C10 & 30 & Protrusion & 10 \\
\hline 14 & P3C15 & 30 & Protrusion & 15 \\
\hline 15 & P3C20 & 30 & Protrusion & 20 \\
\hline 16 & P4Cs & 37.5 & Smooth & ---------- \\
\hline 17 & P4C5 & 37.5 & Protrusion & 5 \\
\hline 18 & P4C10 & 37.5 & Protrusion & 10 \\
\hline 19 & P4C15 & 37.5 & Protrusion & 15 \\
\hline 20 & P4C20 & 37.5 & Protrusion & 20 \\
\hline 21 & P0 & ---------- & -------- & -------- \\
\hline
\end{tabular}

All the experimental treatments received the same agricultural practices as usual in the area. Before beginning the experimental work, soil samples were taken from three locations at the head, the middle and the tail of experimental field. These soil samples were taken for the determination of the soil mechanical analysis, the field capacity, the wilting point and the bulk density according to Anter et al. (1987). Table (2) shows the results of the mechanical analysis and bulk density of the soil. The results showed that the soil texture of the field soil was clay loam; the field capacity and the wilting point were found to be $36 \%$ and $13 \%$ respectively on weight bases. The infiltration rate for the experimental field was measured using double ring according to Hansen et al. (1980). 
The infiltration rate and soil bulk density were measured for all treatments before the first four irrigations. During the execution of the experimental work, soil samples were collected just before each irrigation and two days after irrigation for first irrigation only. To determine the soil moisture content, the samples were taken every 10 meters for each border length. The samples were taken at four depth levels: (0-15), (15-30), (30-45) and $(45-60) \mathrm{cm}$. The total advance time (AT) was measured for first irrigation. The opportunity time (OT) at any point from border inlet was measured at stations $10.0 \mathrm{~m}$ apart long the length of the border for first irrigation only. The depth of water infiltrated into the soil at each station along the length of the border was determined from the opportunity time and behavior of infiltration rate. The depth of the applied water "Da" was determined for first irrigation from mean values of soil moisture content before irrigation for soil layers $(0-60 \mathrm{~cm})$ depth and soil moisture content at field capacity, equation (1). The depth of the water stored in the root zone was calculated from equation (2) according to Hansen et al. (1980). The water distribution uniformity $(\mathrm{Du})$, the water application $\left(\mathrm{E}_{\mathrm{a}}\right)$ and water use efficiency (WUE) were determined from equations (3), (4) and (5) respectively, according to James (1988). At harvest time, the crop yield of each plot was measured for each treatment. The obtained data for the two growing seasons were subjected to proper statical analysis using( M- stat software). The treatment's means were compared using the least signifigant deference (LSD) test at 5\% probability level.

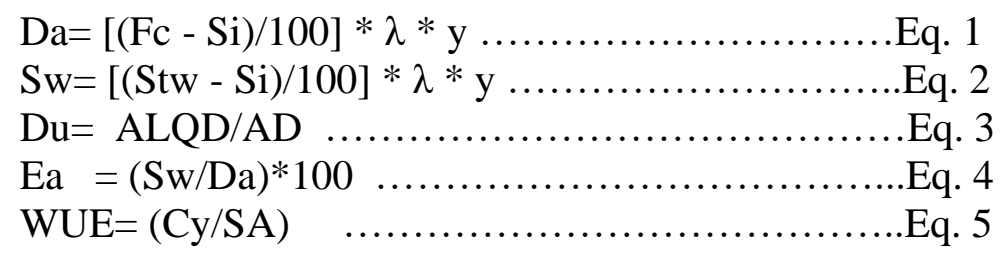

Where:

$\mathrm{Da}=$ the depth of applied water for each irrigation $\mathrm{cm}$;

$\mathrm{Fc}=$ the soil moisture content at field capacity, \%;

$\mathrm{Si}=$ the soil moisture content just before irrigation, \%;

$\lambda=$ the specific bulk density ;

$\mathrm{y}=$ the depth of the root zone, $\mathrm{cm}$;

$\mathrm{Sw}=$ the average depth of the water stored in the root zone, $\mathrm{cm}$; 
$\mathrm{Stw}=$ the soil moisture content after two days of irrigation, \%;

$\mathrm{Du}=$ water distribution uniformity, $\%$;

$\mathrm{ALQD}=$ average depth infiltrated in the lowest one quarter of the area, cm;

$\mathrm{AD}=$ average depth of infiltrated water, $\mathrm{cm}$;

$\mathrm{E}_{\mathrm{a}}=$ the water application efficiency, \%;

WUE=the water use efficiency, $\mathrm{kg} / \mathrm{m}^{3}$;

$\mathrm{Cy}=$ the crop yield for each treatment, $\mathrm{kg} / \mathrm{fed}$;

$\mathrm{SA}=$ seasonal amount of applied water $\mathrm{m}^{3} / \mathrm{fed}$;

\section{RESULTS AND DISCUSSION}

\section{Effect of soil surface compaction pressure $(P)$, compaction cylinder surface shape (C) and irrigation number on the soil bulk density}

The average values of two seasons of soil bulk density for soil layer depth $(0-15 \mathrm{~cm})$ before tillage , after tillage\& before first irrigation and before irrigation number two to before irrigation number five are shown in fig.(3) for all treatments of soil surface compaction. It is clear that the soil bulk density decreased after the soil tillage by $17.2 \%$ compared with that before soil surface tillage. After soil surface compaction pressure the soil bulk density increased by increasing the soil surface compaction pressure from $\mathrm{P} 1$ to $\mathrm{P} 4$ compared with that of uncompacted soil surface.

Before first irrigation, the values of soil bulk density increased over that before the soil was compacted by about $4 \%, 5.6 \%, 8 \%$ and $9.6 \%$ for P1Cs, P2Cs. P3Cs and P4Cs treatments, respectively. So, by increasing soil surface compaction pressure the soil bulk density was increased. The same trend was found for different treatments of cylinder surface shape C5, C10, C15 and C20. The results show also, the cylinder surface shape had not any significant effect on the values of soil bulk density.

Just before irrigation two, the values of soil bulk density increased over that before irrigation one by about $14.32 \%, 10.08 \%, 8.03 \%, 6.06 \%$ and $4.74 \%$ for P0, P1Cs, P2Cs. P3Cs and P4Cs treatments, respectively. So, by increasing soil surface compaction the effect of first irrigation on soil bulk density was decreased. The same trend was found for different treatments of cylinder surface shape C5, C10, C15 and C20. The results 
show also, there were not any significant differences between soil bulk density for all treatments of soil surface compaction pressure and cylinder surface shape before irrigation two. The same trend was found before irrigation three and before irrigation four. Just before irrigation four, the values of soil bulk density reached to the values of soil bulk density before soil tillage. After irrigation four, the irrigation number had not any effect on soil bulk density.

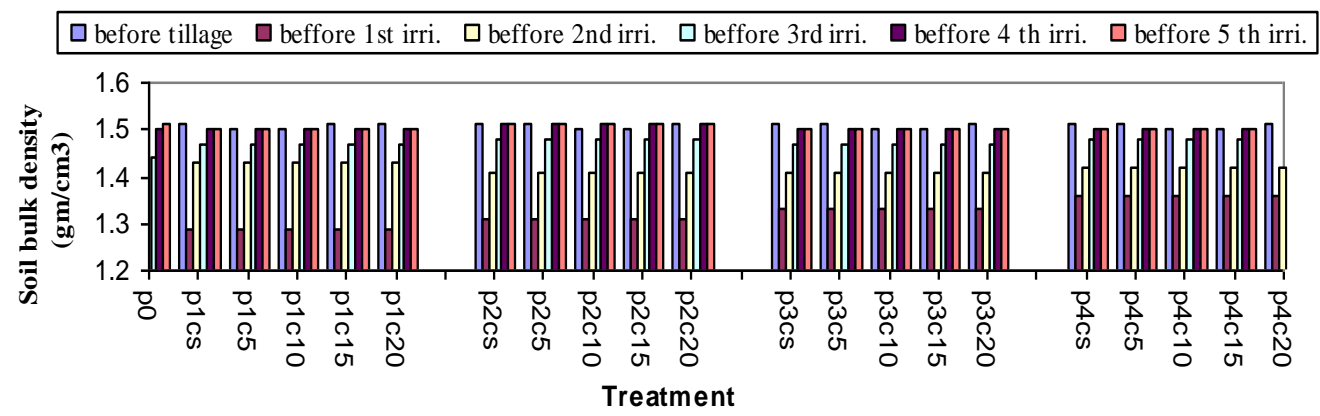

Fig.(3): Effect the values of $\mathrm{P}$ and $\mathrm{C}$ on soil bulk density for different irrigation number.

\section{Effect of soil surface compaction pressure (P), compaction cylinder surface shape $(C)$ and irrigation number on infiltration rate.}

The average values of two seasons of infiltration rate for all treatments of soil surface compaction pressure before irrigation number one are shown in fig.(4). It is clear that the values of infiltration rate of elapsed time less than 20 min decreased by increasing soil surface compaction pressure from P1 to P4, compared with that of uncompacted soil. After 20 min of elapsed time, any treatment of soil surface compaction pressure had the same value of infiltration rate at the same value of elapsed time. So, soil surface compaction pressure had its effect on infiltration rate for elapsed time less than 20 min only. In this range of elapsed time the values of infiltration rate were decreased by increasing soil surface compaction from P1 to P4. The results show also, the cylinder surface shape had not any effect on the values of infiltration rate at any elapsed time.

The values of infiltration rate Just before second irrigation are shown in fig.(5) for all treatments of soil surface compaction pressure. It is clear that the values of infiltration rate for all treatments decreased less than those before irrigation one at the same elapsed time. 


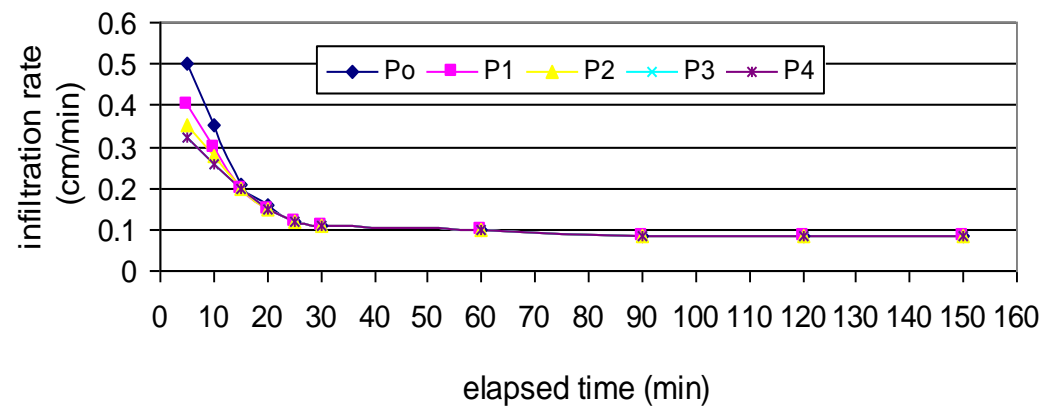

Fig. (4): Effect the values of $P$ on infiltration rate before first irrigation

The infiltration rate had the same value for all treatments of soil surface compaction pressure at the same elapsed time. So, after first irrigation and before second irrigation, the soil surface compaction pressure treatment lost its effect on infiltration rate and became had not any effect on its value. The same trend was found for infiltration rate behavior before irrigation number three, fig.(6).

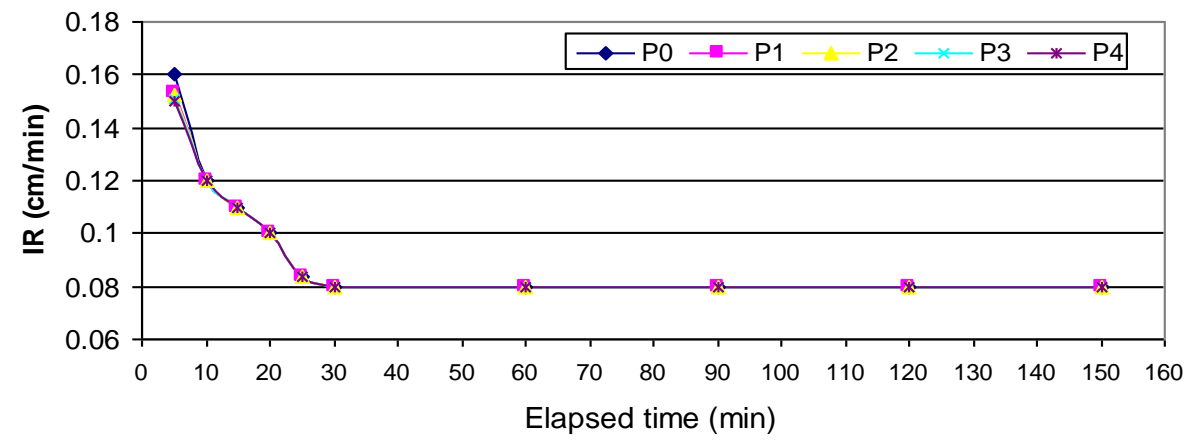

Fig. (5): Effect the values of $\mathrm{P}$ on infiltration rate before second irrigation

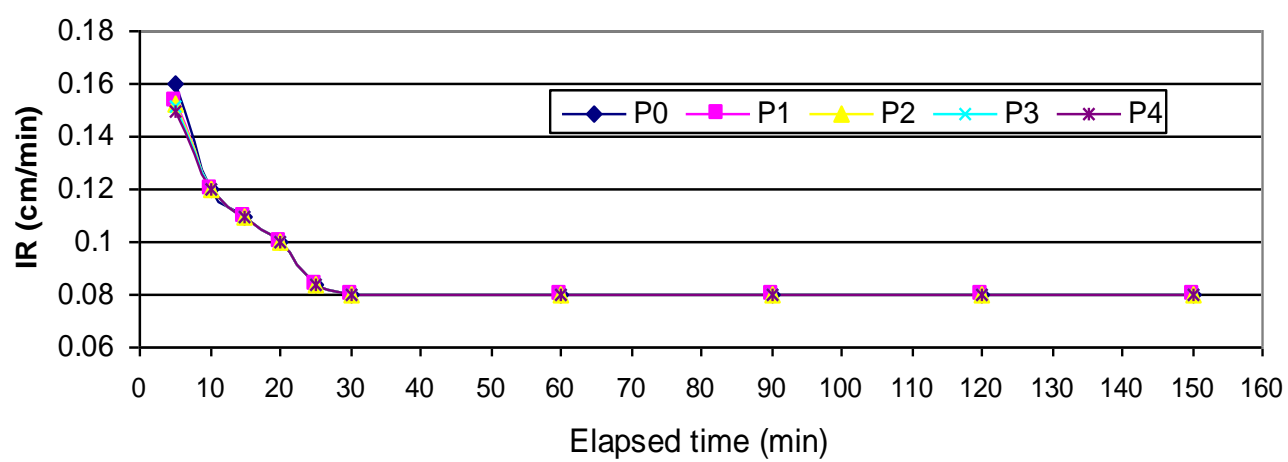

Fig. (6): Effect the values of $\mathrm{P}$ on infiltration rate before third irrigation 


\section{Effect of soil surface compaction pressure (P) and compaction}

cylinder surface shape (C) on the total advance time (AT) for first irrigation.

The average values of two seasons of total advance time to the field end (AT) for first irrigation are shown in fig (7). It is clear that the total advance time decreased for all treatments of soil surface compaction pressure and cylinder surface shape compared with that for uncompacted soil. The total advance time for the compacted soils by smooth cylinder surface shape "Cs" decreased than that for un-compacted soil by 8, 15, 19 and $19 \%$ for P1, P2, P3 and P4 where its corresponding values were 15, 22.5, 30 and $37.5 \mathrm{kPa}$, respectively. So, by increasing the soil compaction pressure from $\mathrm{P} 1$ to $\mathrm{P} 2$ decreased the advance time. The same trend was found for different toothed cylinder surface shapes C5, C10, $\mathrm{C} 15$ and $\mathrm{C} 20$.

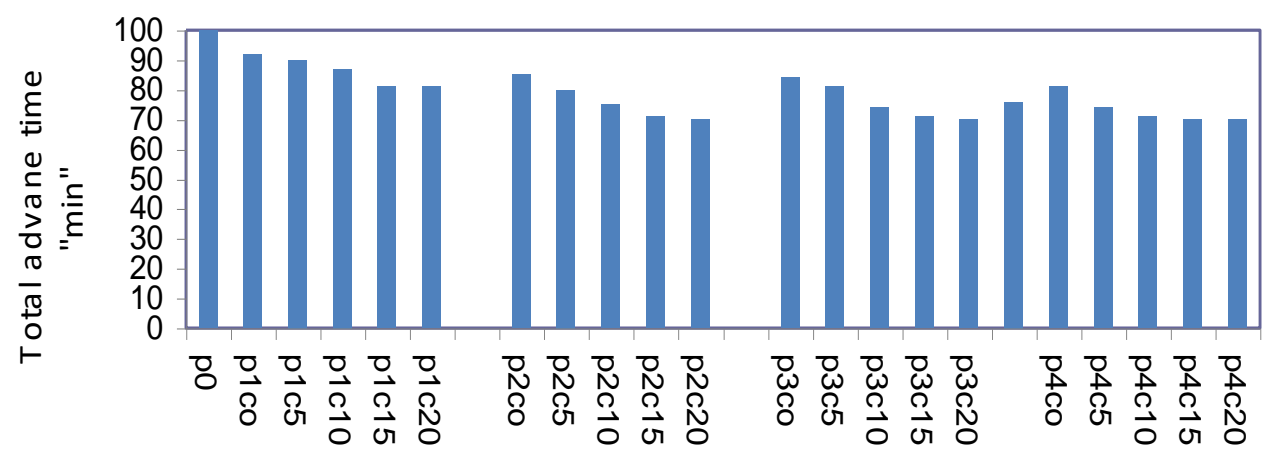

Treatment

Fig. (7): Effect the values of $\mathrm{P}$ and $\mathrm{C}$ on total advane time

At the same "P" value. The total advance time decreased for all treatments of compacted soils by toothed cylinder surface shape "C" compared with that for treatments of soils were compacted by smooth cylinder "Cs" surface shape. For toothed cylinder surface shape, increasing the distance between the prominence from $5 \mathrm{~cm}$ to $15 \mathrm{~cm}$ decreased the values of advance time. For example, at soil surface pressure P1, $15 \mathrm{kPa}$, The total advance time for the compacted soils by toothed cylinder surface shape decreased than that for compacted soils by smooth cylinder surface shape by $5.4,9.7,11.95$ and $11.95 \%$ for $5,10,15$ and $20 \mathrm{~cm}$ tooth's distance, 
respectively. There were not any significant difference between the values of advance time by increasing the distance between tooth from 15 and $20 \mathrm{~cm}$. The minimum value of total advance time to the field end for first irrigation was about $70 \mathrm{~min}$ for $\mathrm{P} 2 \mathrm{C} 15, \mathrm{P} 3 \mathrm{C} 15$ and $\mathrm{P} 4 \mathrm{C} 15$. Meanwhile the total advance time value was $100 \mathrm{~min}$ for un-compacted soil. The irrigation time for first irrigation was determined from the amount of applied water for first irrigation and the discharge rate for each border, it was found to be $90 \mathrm{~min}$. The previous by mentioned results indicated that the advance time value of the first irrigation were decreased for all treatments of soil surface compaction pressure and cylinder surface shape, compared with that for un-compacted soil (P0). Also, by increasing the values of $\mathrm{C}$ from 5 to 15 the advance time decreased. These results may be due to the decreasing of infiltration rate and the roughness coefficient of the surface soil by the compaction process.

\section{Effect of soil surface compaction pressure (P) and compaction cylinder surface shape (C) on the opportunity time for first irrigation.}

The average values of two seasons of opportunity time for each station (OT) and distribution uniformity of these values for first irrigation are shown in figures 8 and 9, respectively. From fig. (8), it is clear that the difference between opportunity time values for different stations decreased for all treatments of soil surface compaction pressure and cylinder surface shape compared with that for uncompacted soil.

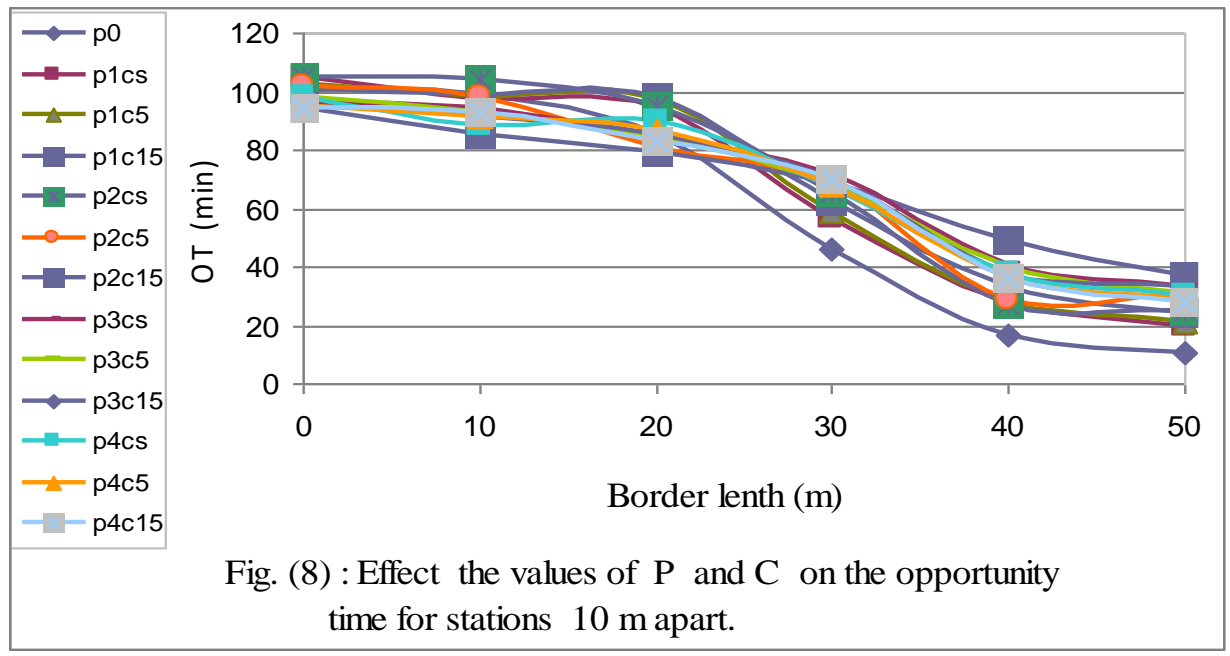


Distribution Uniformity of opportunity times were determined for each treatment, fig.(9). It is clear that the distribution uniformity of opportunity time increased for all treatments of soil compaction pressure and cylinder surface shape compared with that for uncompacted soil. By increasing the soil compaction pressure from P1 to P2 increased the distribution uniformity of opportunity time, while it had not any significant effect by increasing the soil compaction pressure from P2 to P4. At the same "P" value, the opportunity time uniformity increased for all treatments of compacted soils by toothed cylinder surface shape "C" compared with that for treatments of soils were compacted by smooth cylinder "Cs" surface shape. For toothed cylinder surface shape, increasing the distance between the prominences from $5 \mathrm{~cm}$ to $15 \mathrm{~cm}$ increased distribution uniformity of opportunity time, while it had not any significant effect if the distance between the prominences was increased to $20 \mathrm{~cm}$. The maximum value for distribution uniformity of opportunity time for first irrigation "62.5\%" was obtained at treatment P2C15, while the minimum value was "22\% obtained at treatment P0.

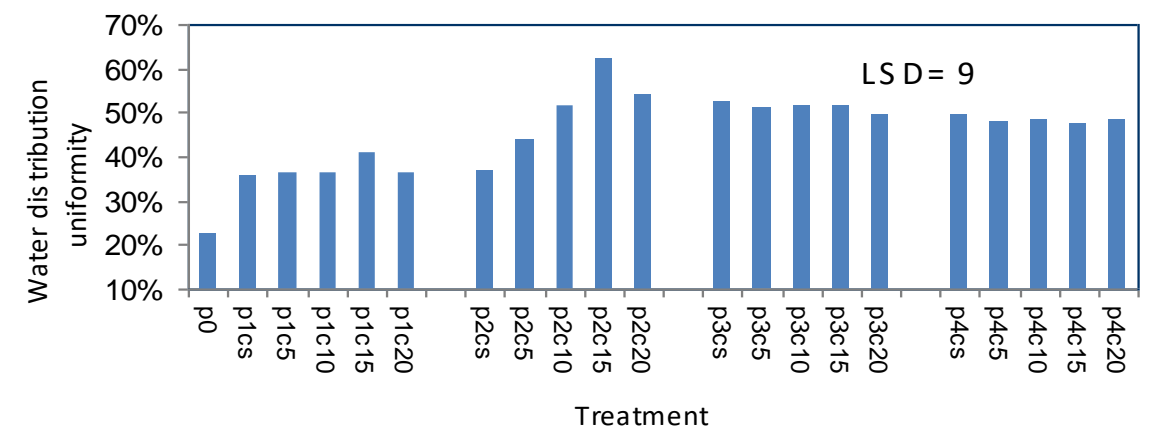

Fig. ( 9 ) : E ffect the values of $P$ and $C$ on distribution uniformity of opportunity time

\section{Effect of soil surface compaction pressure (P) and compaction cylinder surface shape (C) on the depth of water infiltrated for first irrigation.}

The total depth of the infiltrated water in to the soil for first irrigation was determined at the beginning and the end of each station for first irrigation. The infiltrated water was determined from the opportunity time at each station, fig. (8) and the behavior of the infiltration rate, fig.(4). The depths of infiltrated water in to the soil for some different treatments are shown in table (2). The depth of water needed to increase the soil profile at the root zone $(60 \mathrm{~cm})$ to the field capacity was determined to be $" 9.9 \mathrm{~cm}$." 
Table (2) shows that many locations of the border received depth of water enough to increase the moisture more than the field capacity except the last two stations for most treatments, which they received a total amount of water less than $9.9 \mathrm{~cm}$. Any water infiltrated greater than $9.9 \mathrm{~cm}$ at any station was considered as water losses.

Table (2): Effect the values of (P) and (C) on the depth of water infiltrated for first irrigation

\begin{tabular}{||c|c|c|c|c|c|c||}
\hline \multirow{2}{*}{ Treatment } & \multicolumn{7}{|c|}{ The distance from inlet $(\mathrm{m})$} \\
\cline { 2 - 7 } & 0 & 10 & 20 & 30 & 40 & 50 \\
\hline P0 & 13.90 & 13.80 & 12.70 & 9.10 & 5.40 & 4.30 \\
\hline P1Cs & 13.42 & 12.80 & 12.55 & 9.20 & 6.15 & 5.10 \\
\hline P1C5 & 13.3 & 12.80 & 12.40 & 9.70 & 6.20 & 5.20 \\
\hline P1C10 & 13.3 & 12.90 & 12.35 & 9.60 & 6.30 & 5.15 \\
\hline P1C15 & 13.00 & 12.70 & 12.70 & 9.80 & 5.90 & 5.20 \\
\hline P1C20 & 13.24 & 13.00 & 12.67 & 9.30 & 5.80 & 5.16 \\
\hline P2Cs & 12.90 & 12.80 & 12.50 & 9.94 & 5.70 & 5.30 \\
\hline P2C5 & 12.70 & 12.50 & 11.30 & 10.90 & 5.61 & 5.80 \\
\hline P2C10 & 12.50 & 11.65 & 11.20 & 10.71 & 6.87 & 5.80 \\
\hline P2C15 & 11.87 & 11.40 & 11.00 & 10.80 & 7.30 & 6.80 \\
\hline P2C20 & 11.91 & 11.91 & 11.62 & 10.71 & 7.21 & 5.80 \\
\hline P3Cs & 11.83 & 11.80 & 11.40 & 11.00 & 7.10 & 5.82 \\
\hline P3C5 & 11.90 & 11.80 & 11.41 & 10.95 & 7.10 & 5.80 \\
\hline P3C10 & 11.90 & 11.78 & 11.41 & 10.90 & 7.00 & 5.81 \\
\hline P3C15 & 11.81 & 11.72 & 11.42 & 10.98 & 7.00 & 5.83 \\
\hline P3C20 & 11.83 & 11.69 & 11.42 & 11.00 & 6.95 & 5.80 \\
\hline P4Cs & 11.90 & 11.90 & 11.70 & 10.90 & 6.60 & 5.90 \\
\hline P4C5 & 11.97 & 11.85 & 11.40 & 10.85 & 7.00 & 6.10 \\
\hline P4C10 & 11.90 & 11.78 & 11.70 & 10.90 & 7.00 & 6.00 \\
\hline P4C15 & 11.81 & 11.72 & 11.42 & 10.85 & 7.30 & 6.20 \\
\hline P4C20 & 11.83 & 11.69 & 11.42 & 11.00 & 6.95 & 5.80 \\
\hline
\end{tabular}

Note: The stations suffering water defect are hatched.

Fig. (10) Shows the percentage of water losses by deep percolation. The percentage of water losses by deep percolation decreased by increasing the soil surface compaction pressure from P1 to P2, while it had not any significant effect if the soil surface compaction pressure increased to P3. At the same "P" value, the percentage of water losses by deep percolation increased for all treatments of compacted soils by toothed cylinder 
surface shape "C" compared with that for treatments of soils were compacted by smooth cylinder "Cs" surface shape. For toothed cylinder surface shape, increasing the distance between the prominences from 5 $\mathrm{cm}$ to $15 \mathrm{~cm}$ decreased the water losses by deep percolation, while it had not any significant effect if the distance between the prominences was increased to $20 \mathrm{~cm}$. The minimum value of percentage of water losses by deep percolation for first irrigation "9.2\%" was obtained at treatment $\mathrm{P} 2 \mathrm{C} 15$, while the maximum value was "18\%" was obtained at treatment $\mathrm{P} 0$ for first irrigation too.

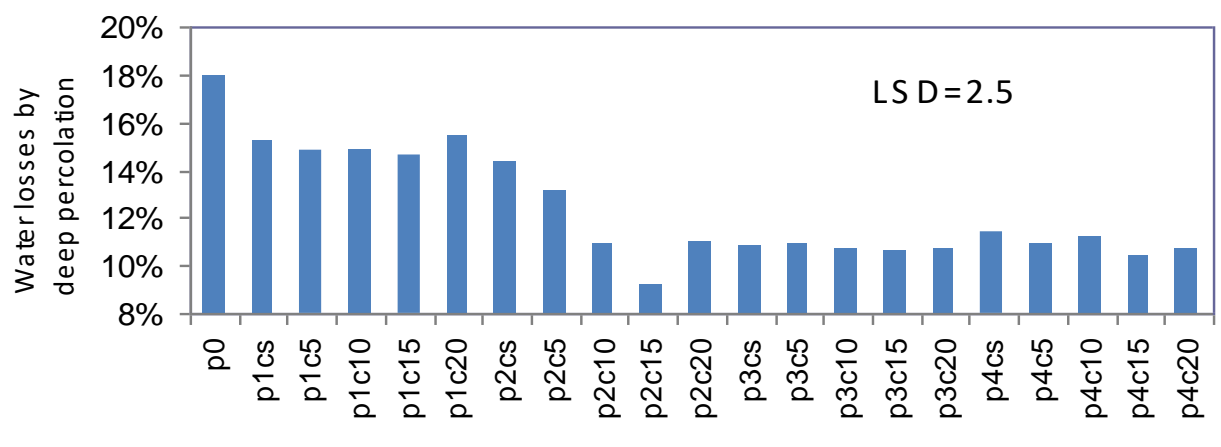

Treatment

Fig. (10): Effect the values of $P$ and $C$ on the percentage of water losses by deep pecolation.

Any station received depth of water less than $9.9 \mathrm{~cm}$ was considered as soil moisture defect. Fig.(11) shows the percentage of soil moisture defect (SMD). The percentage of soil moisture defect was decreased by increasing the soil compaction pressure from P1 to P2. At the same "P" value, the percentage of soil moisture defect decreased for all treatments of compacted soils by toothed cylinder surface shape compared with that for treatments of soils were compacted by smooth cylinder surface shape "Cs". For toothed cylinder surface shape, increasing the distance between the prominences from $5 \mathrm{~cm}$ to $15 \mathrm{~cm}$ decreased the percentage of soil water defect. The maximum value of the percentage of soil water defect for first irrigation "28.8\%" was obtained at treatment P2C15, while the minimum value was $51 \%$ obtained at treatment $\mathrm{P} 0$. 


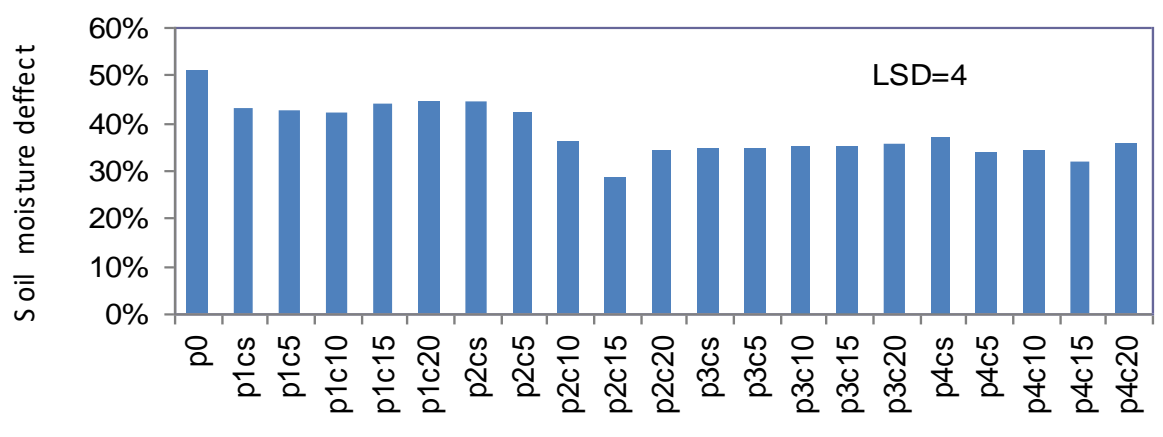

Treatment

Fig. (11) : Effect the values of of $\mathrm{P}$ and $\mathrm{C}$ on soil moisture defect.

6. Effect of soil surface compaction pressure (P) and compaction cylinder surface shape (C) on water distribution uniformity and water application efficiency for first irrigation.

From the depth of water infiltrated, water distribution uniformity "Du" and water application efficiency "Ea" were determined according to equations (3) and (4), respectively. The values of water distribution uniformity and water application efficiency are shown in fig.(12), From figure (12), it is clear that the water distribution uniformity increased for all treatments of soil surface compaction pressure and cylinder surface shape compared with that for uncompacted soil.

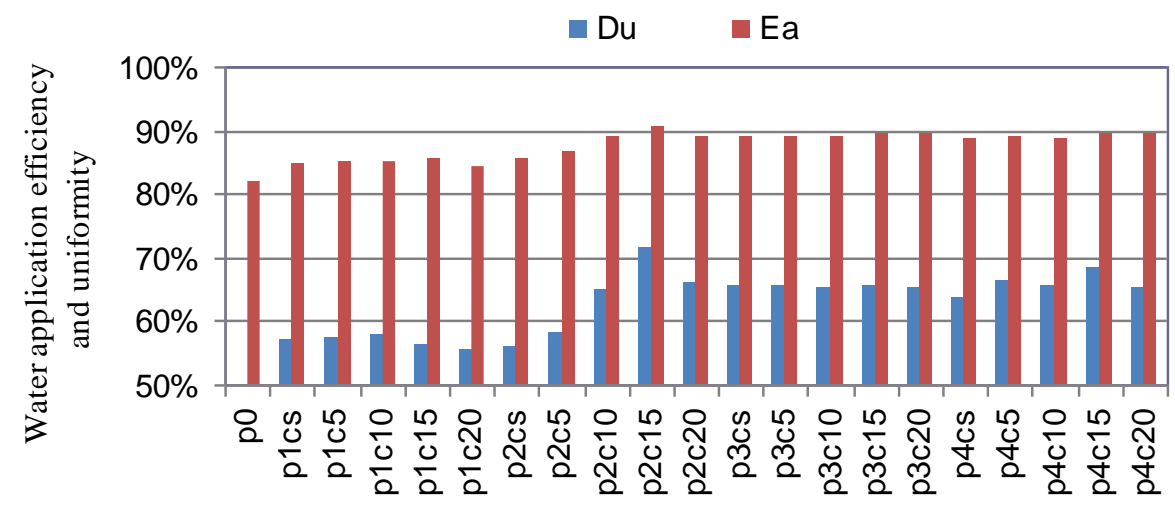

Treatment

Fig. (12) : Effect the values of $\mathrm{Pi}$ and $\mathrm{C}$ on water aplication efficiency"Ea" and water distribution uniformity "Du".

By increasing the soil surface compaction pressure from P1 to P2 increased the water distribution uniformity, while it had not any 
significant effect by increasing the soil compaction pressure from P2 to $\mathrm{P} 4$. At the same "P" value, the water distribution uniformity increased for all treatments of compacted soils by toothed cylinder surface shape compared with that for treatments of soils were compacted by smooth cylinder surface shape "Cs". For toothed cylinder surface shape, increasing the distance between the prominences from $5 \mathrm{~cm}$ to $15 \mathrm{~cm}$ increased water distribution uniformity, while it had not any significant effect if the distance between the prominences was increased to $20 \mathrm{~cm}$. The maximum value for distribution uniformity of opportunity time for first irrigation "71.49 \%" was obtained at treatment P2C15, while the minimum value was "49.16\%" obtained at treatment $\mathrm{P} 0$. The same trend was found for water application efficiency. The maximum value of water application efficiency for first irrigation "90.79 \%" was obtained at treatment $\mathrm{P} 2 \mathrm{C} 15$, while the minimum value was "81.99\%" obtained at treatment $\mathrm{P} 0$.

\section{Effect of soil surface compaction pressure (P) and compaction cylinder surface shape $(C)$ on corn crop yield and water use efficiency.}

The mean values of two seasons for the results related to the yield of corn crop "Cy" and water use efficiency "WUE" are shown in table (3).

The data shown that the yield of corn crop increased for all treatments of soil compaction pressure and cylinder surface shape compared with that for uncompacted soil. By increasing the soil compaction pressure from P1 to P2 increased the yield of corn crop, while it had not any significant effect by increasing the soil compaction pressure from $\mathrm{P} 2$ to $\mathrm{P} 4$. At the same "P" value, the cylinder surface shape " $\mathrm{C}$ " had not any significant effect on the yield of corn crop. The maximum value for the yield of corn crop for first irrigation "3050 kg/fed" was obtained at treatments P2C15 and P3C15 while the minimum value was "2430 kg/fed " was obtained at treatment (P0). The seasonal amount of applied water was measured and was found "2941 m3/fed". The same trend of corn crop yield was found for water use efficiency. The maximum value of the water use efficiency "1.037 kg/m 3 " was obtained at treatments P2C15 and P3C15 while the minimum value was $" 0.826 \mathrm{~kg} / \mathrm{m}^{3}$ " obtained at treatment $\mathrm{P} 0$. The corn crop yield and water use efficiency for compacted soil treatments P2C15 and $\mathrm{P} 3 \mathrm{C} 15$ increased than that for uncompacted soil "P0" by $25.5 \%$. 
Table (3): Effect of soil surface compaction pressure (P) and compaction cylindersurface shape $(C)$ on the yield of corn crop and water use efficiency.

\begin{tabular}{|c|c|c|}
\hline Treatment & Corn crop yield, $\mathrm{kg} / \mathrm{fed}$ & Water use efficiency, $\mathrm{kg} / \mathrm{m}^{3}$ \\
\hline $\mathrm{P} 0$ & 2430 & 0.826 \\
\hline $\mathrm{p} 1 \mathrm{cs}$ & 2510 & 0.853 \\
\hline $\mathrm{p} 1 \mathrm{c5}$ & 2525 & 0.858 \\
\hline $\mathrm{p} 1 \mathrm{c} 10$ & 2487 & 0.845 \\
\hline $\mathrm{p} 1 \mathrm{c} 15$ & 2510 & 0.853 \\
\hline $\mathrm{p} 1 \mathrm{c} 20$ & 2497 & 0.849 \\
\hline $\mathrm{p} 2 \mathrm{cs}$ & 2957 & 1.005 \\
\hline $\mathrm{p} 2 \mathrm{c5}$ & 2990 & 1.017 \\
\hline $\mathrm{p} 2 \mathrm{c} 10$ & 3035 & 1.032 \\
\hline $\mathrm{p} 2 \mathrm{c} 15$ & 3050 & 1.037 \\
\hline $\mathrm{p} 2 \mathrm{c} 20$ & 3040 & 1.034 \\
\hline $\mathrm{p} 3 \mathrm{cs}$ & 2967 & 1.009 \\
\hline $\mathrm{p} 3 \mathrm{c5} 5$ & 3000 & 1.020 \\
\hline $\mathrm{p} 3 \mathrm{c} 10$ & 3040 & 1.034 \\
\hline $\mathrm{p} 3 \mathrm{c} 15$ & 3050 & 1.037 \\
\hline $\mathrm{p} 3 \mathrm{c} 20$ & 3040 & 1.034 \\
\hline $\mathrm{p} 4 \mathrm{cs}$ & 2989 & 1.016 \\
\hline $\mathrm{p} 4 \mathrm{c5} 5$ & 2970 & 1.010 \\
\hline $\mathrm{p} 4 \mathrm{c} 10$ & 2980 & 1.013 \\
\hline $\mathrm{p} 4 \mathrm{c} 15$ & 3000 & 1.020 \\
\hline $\mathrm{p} 4 \mathrm{c} 20$ & 3025 & 1.028 \\
\hline
\end{tabular}

LSD for "Cy" = 78

LSD for "WUE" $=0.0265$

\section{CONCLUSION}

The purpose of this research work is to explore the effect of different levels of soil surface compacting pressure $(\mathrm{P})$ and compacting cylinder surface shapes $(C)$ on the values of soil bulk density $(\lambda)$, infiltration rate (IR), total advance time (AT),), percentage of water losses by deep percolation (Dpp), percentage of soil moisture defect (SMD), water distribution uniformity $(\mathrm{Du})$, water application efficiency $\left(\mathrm{E}_{\mathrm{a}}\right)$, corn crop yield (Cy), and water use efficiency (WUE). The results indicated that:

1. The values of (AT), (DPP) and (SMD) decreased for all treatments of soil surface compaction pressure $(\mathrm{P})$ and cylinder surface shapes $(\mathrm{C})$ 
compared with that for uncompacted soil (P0). By increasing the value of $(\mathrm{P})$ from $\mathrm{P} 1$ to $\mathrm{P} 2$, all above parameters decreased for different cylinder surface shapes $(\mathrm{C})$.

2. At the same value of (P), the values of (AT), (DPP) and (SMD) decreased for all treatments of compacted soils by toothed cylinder surface shape compared with that for treatments of soils were compacted by smooth cylinder surface shape "Cs". By increasing the distance between the prominence from $5 \mathrm{~cm}$ to $15 \mathrm{~cm}$ decreased the values of AT), (DPP) and (SMD)

3. The minimum values of (AT), (DPP) and (SMD) "70 min", "9.2\%", "28.8\%", respectively were obtained at treatment P2C15 , P3C15 and P4C15. Meanwhile the maximum values of these parameters "100 min", "18\%" and "51\%" were obtained at treatment P0.

4. The values of (Du), (Ea), (Cy), and (WUE) increased for all treatments of soil surface compaction pressure $(\mathrm{P})$ and cylinder surface shapes $(\mathrm{C})$ compared with that for uncompacted soil (P0). By increasing the value of $\mathrm{P}$ from $\mathrm{P} 1$ to $\mathrm{P} 2$ for parameters $(\mathrm{Du}),(\mathrm{Ea})$, (Cy), and (WUE) increased for different compacting cylinder surface shapes (C).

5. The maximum values of (Du), (Ea), (Cy), and (WUE) "71.49\%", "90.79 \%" , "3050 kg/fed" and "1.037 kg/m3", respectively were obtained at treatment $\mathrm{P} 2 \mathrm{C} 15$ and $\mathrm{P} 3 \mathrm{C} 15$. Meanwhile the minimum values of these parameters "49.16\%", "81.99\%", "2430 kg/fed" and " $0.826 \mathrm{~kg} / \mathrm{m}^{3 "}$ were obtained at treatment P0.

\section{REFEERENCES}

Allen, R.R. and A.D. Schneirder. 1992 Furrow water intake reduction with surge irrigation or traffic compaction . J. Applied Engineering in Agriculture . AS AE.8(4):455-460

Anter, I.; M. Negmand and M. I. Mecheal. 1987. Analysis methods of agricultural soils. Soil and Water Res. Inst.Agric.Res.Center., Tech. Report(8):1-22.

Boone, F.S.1988. Whether and other environmental factors influencing cropresponses to tillage and traffic. Soil and Tillage Research (11):283-324. 
EWUP, Egypt Water Use and Management Project. 1984. Improving Egypt system in the old lands. EWUP Final Report International Press:85p.

Gemtos, T. A. and T.H. Lellis . 1997. Effect of soil compaction, water and organic mater on emergence and initial growth of cotton and surge beet. J. Agric. Eng. Resch. 66(4):121-137

Ghonimy, M. I. 2003. Analytical approach to energy balance in seed-bed preparation for corn crop. Misr J. Ag. Eng., 20 (1): 1-17.

Hansen, V.E.; O. W. Israelson and G. E. Stringham. 1980. Irrigation principles and practices. John. Willey and Sons, Inc.N.Y

James,L.C.1988.Principles of Farm Irrigation System Design. New York. Willey:230p.

Schwankl, L. J.; N. S. Raghuwanshi, and W. W. Wallender. 2000. Furrow irrigation performance under spatially varying conditions. J. of Irrigation and Drainage Engineering, ASCE 126(6): 355-361.

Soane, B.D.; J.W. Dickson and D.J.Campbell.1982. Incidence and control of compaction in crop production . Soil and Tillage Reseach $.12(3): 13-36$

Voorhees, W.B.1987. Assessment of soil susceptibility to compaction using soil and climatic data. Soil and Tillage Research.10(3):29-38.

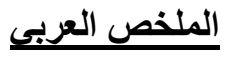

تأثير ضغط كبس سطح التربة وأشكال سطح اسطوانة الكبس على كفاءة الري بالشرائح

محمد عبد الوهاب قاسم* محمد إبراهيم غنيمي** جمال منصور عبدالرحمن*

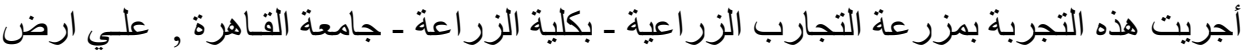

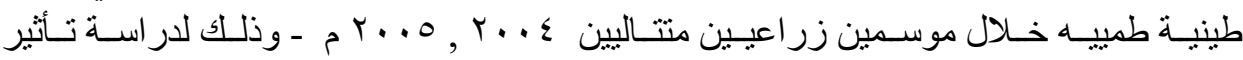

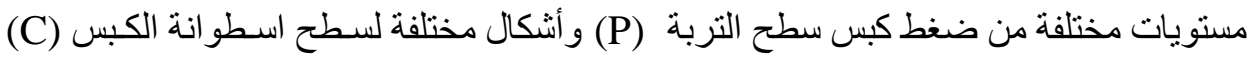

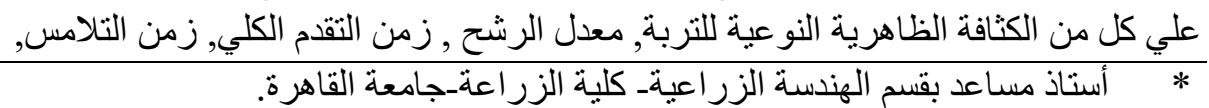

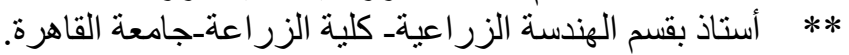




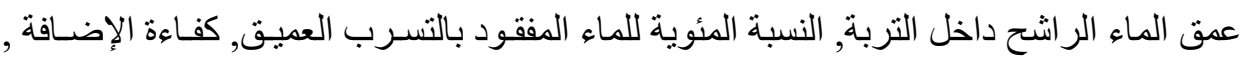

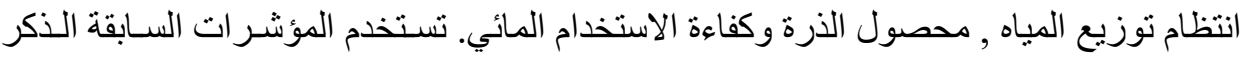
لتحديد أفضل ضغط لكبس سطح التربة و أفضل شكل لاسطو انة الكبس - و لإجر اء هذه التجربة تم التم

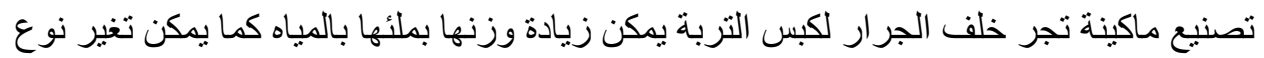

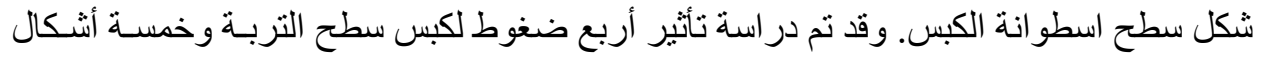

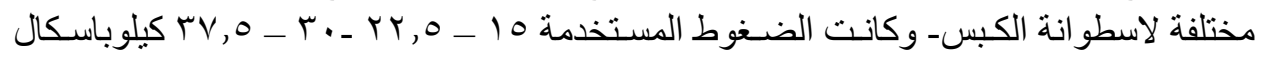

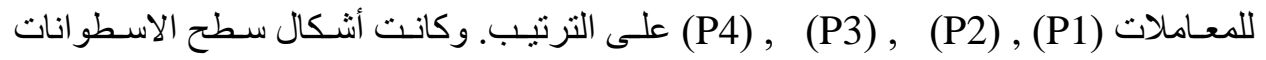

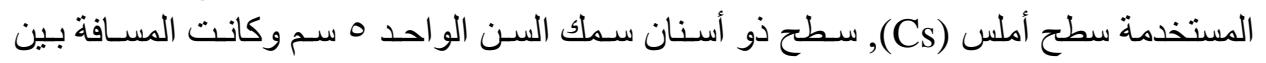

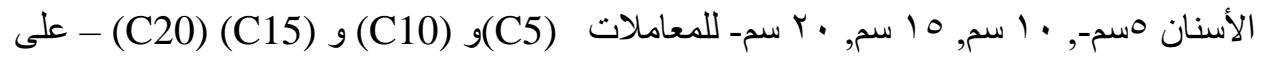

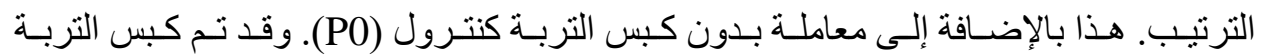

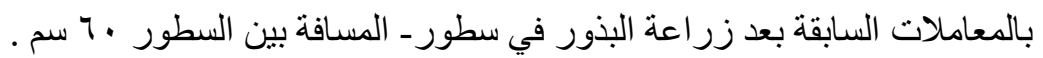

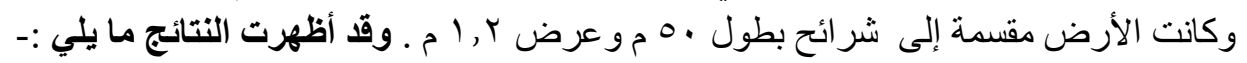

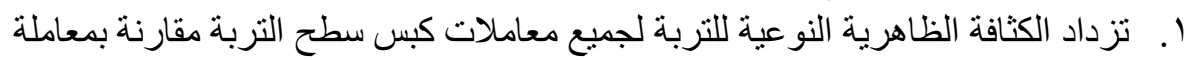

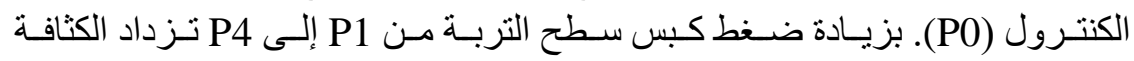

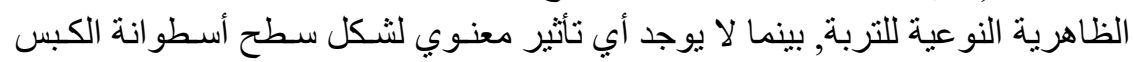
على قيم الكثافة الظاهرية النو عية للتربة.

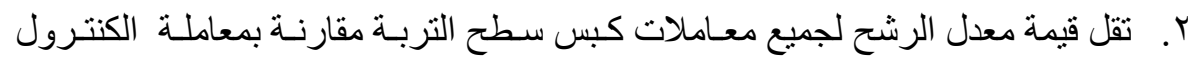

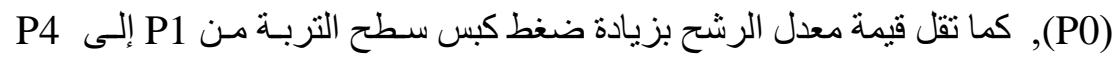

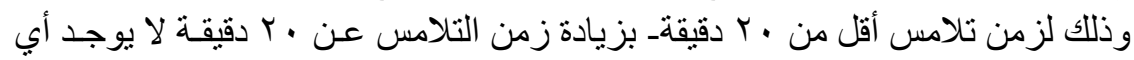

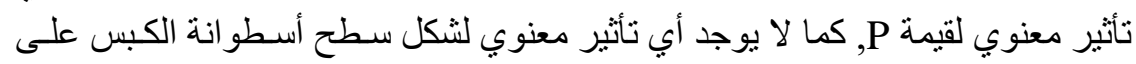
قيم معدل الرشح لأي زمن من أزمنة التنلامس.

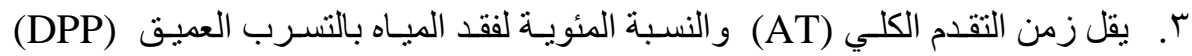

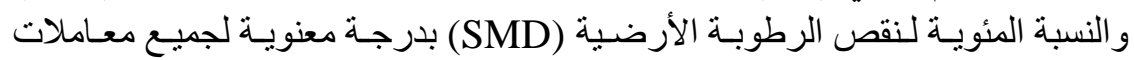

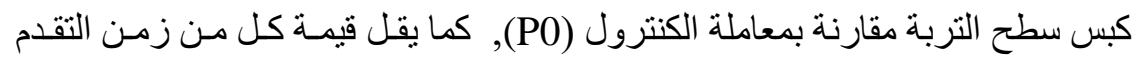

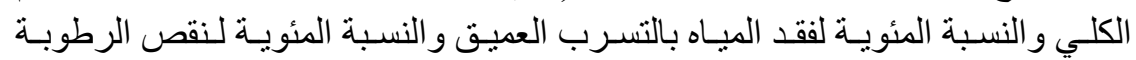

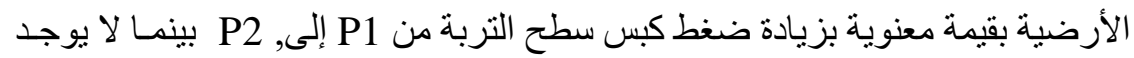

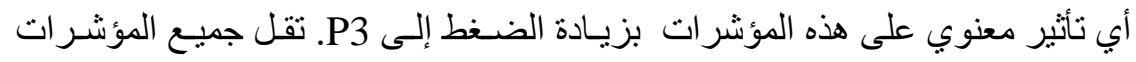

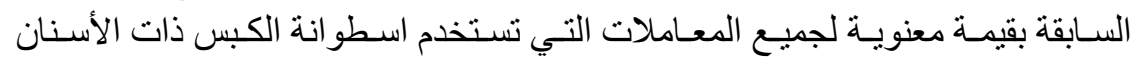

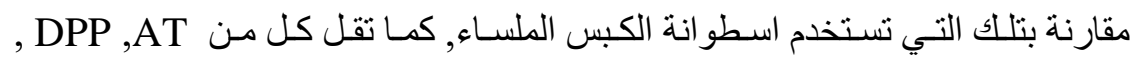
SMD

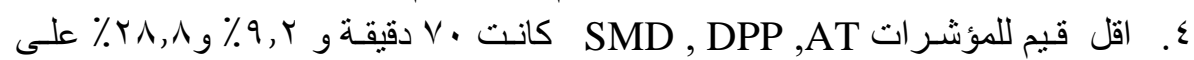

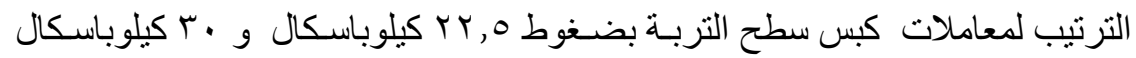
باسطو انة ذات أسنان المسافة بين الأسـنان 0 استم

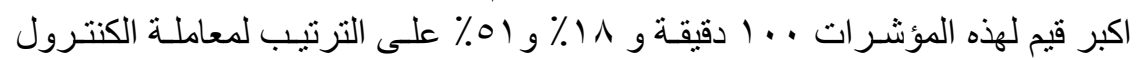




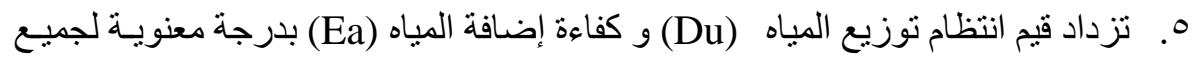

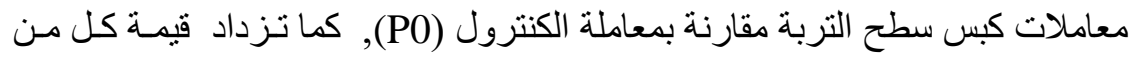

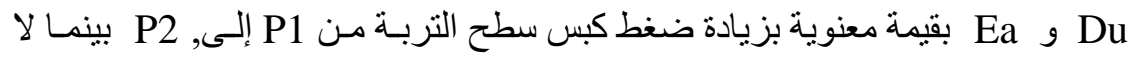

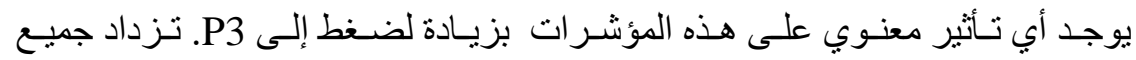

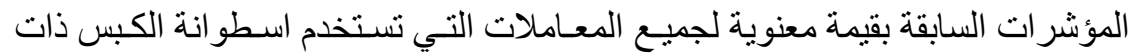

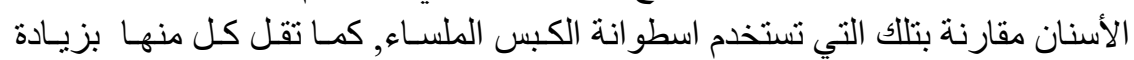

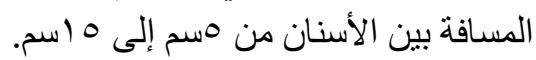

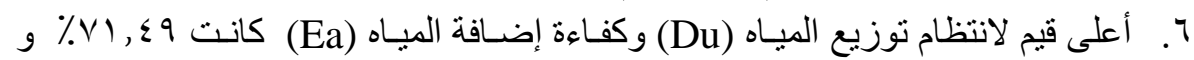

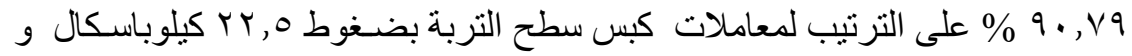

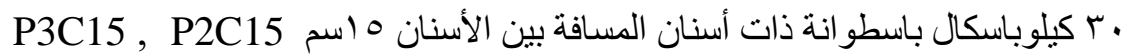

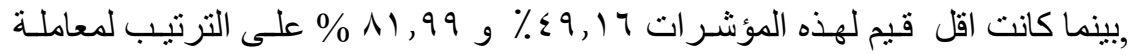

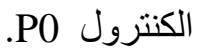

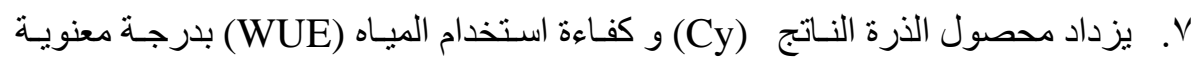

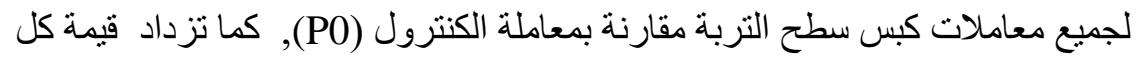

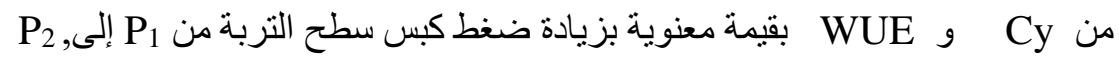

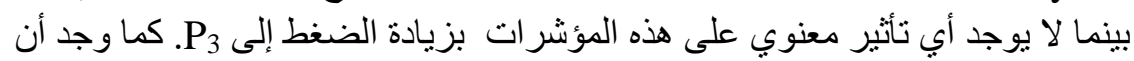

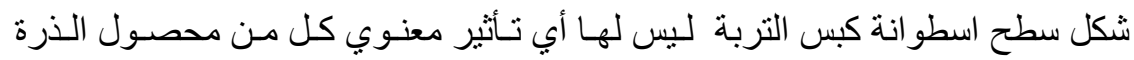
الناتج أو كفاءة استخدام المباه.

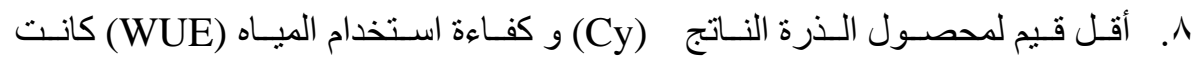

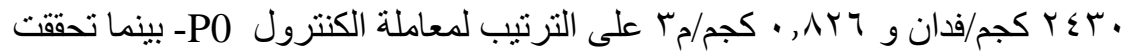

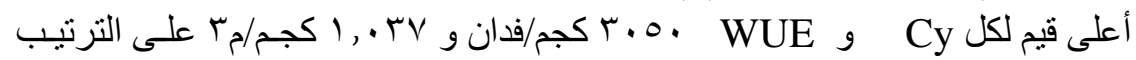
للمعاملات P2C15 , P3C15. 